Corporate Governance Mechanisms and Accounting Conservatism:

Evidence from Egypt

Mahmoud A. Nasr ${ }^{\mathrm{a} 1, \mathrm{c}}$, Collins G. Ntim ${ }^{\mathrm{b}}$

${ }^{a}$ Department of Accounting

Faculty of Commerce

Alexandria University

Alexandria, Egypt

${ }^{\mathrm{b}}$ Department of Accounting

Centre for Research in Accounting, Accountability and Governance

Southampton Business School

University of Southampton

Southampton, SO17 1BJ, UK

${ }^{\mathrm{c}}$ Department of Accountancy and Finance

Business School

Huddersfield University

Huddersfield, HD1 3DH, UK

${ }^{1}$ Corresponding author: Department of Accounting, Faculty of Commerce, Alexandria University, Egypt. E-mail: mah.abdelhamidnasr@gmail.com 


\title{
Corporate Governance Mechanisms and Accounting Conservatism: \\ Evidence from Egypt
}

\begin{abstract}
Purpose: This paper investigates the effect of corporate governance (CG) mechanisms (board size, board independence, separation of chairman and CEO roles, and external auditor type) on accounting conservatism in Egypt.

Design/methodology/approach: Archival data relating to $\mathrm{CG}$ and accounting conservatism are collected and analysed using multivariate regression techniques.

Findings: The findings indicate that board independence is positively associated with accounting conservatism. By contrast, board size and auditor type are negatively associated with accounting conservatism, while separating the chairperson and CEO roles has no significant relationship with accounting conservatism.

Originality/value: To the best of our knowledge, this is one of the first empirical attempts at providing evidence on the relationship between corporate governance and accounting conservatism in Egypt.
\end{abstract}

Keywords: Corporate governance, accounting conservatism, Egypt

Paper type: Research paper 


\section{Introduction}

This paper investigates the effect of corporate governance $(\mathrm{CG})$ mechanisms on the extent of accounting conservatism in Egypt. Separation between a firm's principals (shareholders) and managers (insiders) can result in managers having greater access to information relating to its operations and management (Abdulrahman et al., 2017; Ntim et al., 2017a, b). Meanwhile the primary source of information for shareholders is financial statements published by management. Shareholders are always concerned with how managers implement the principles of accounting conservatism in their financial estimates, as this often results in better protection for shareholders (Cuillinan et al., 2012; Elamer et al., 2017). One reason for the increasing interest in accounting conservatism is that not all areas of accounting are covered by accounting standards (Chung et al., 2003; Elmagrhi et al., 2016, 2017), with some areas requiring a manager's judgment, which could range from neutral or aggressive, and finally to conservative behaviour and decisions. Therefore, the level of accounting conservatism arguably depends on a manager's estimates.

In order to control managers' estimates and maintain conservative reporting, managers should be monitored by instituting a number of CG mechanisms. For instance, the presence of a large number of outsiders on the board can enhance the monitoring process, making managers more conservative in their financial reporting (García` Lara et al., 2007; Elghuweel et al., 2017). Several studies suggest that CG mechanisms can enhance the level of accounting conservatism (Ahmed \& Duellman 2007; Ahmed \& Henry 2012; Elshandidy \& Hassanein, 2014; Kukah et al., 2016). Indeed, other studies have demonstrated that CG mechanisms, such as board size and board independence, can reduce accounting conservatism (Chi et al., 2009; Lim, 2011). Meanwhile previous literature emphasises that effective CG mechanisms restrict a manager's opportunistic behaviour, and thus induce them to be more conservative in their financial reporting. However, the link between CG mechanisms and accounting conservatism varies across different institutional settings. For instance - and using a sample of US firms - Lara, Osma, and Penalava (2009) note that there is a positive association between CG mechanisms and the level of accounting conservatism. Similarly, Lim (2011) evinces that CG attributes enhance the level of accounting conservatism in Australian firms. This study, therefore, examines the effect of CG attributes on the level of accounting conservatism in Egypt. As with the CG mechanisms examined in previous literature, the common CG mechanisms that have been used in past studies include board size, board independence, separation between the roles of chairman and CEO positions, and auditor type.

Noticeably, the decision to focus on Egypt is motivated by a number of reasons. First, most empirical evidence examining the association between CG and accounting conservatism has been conducted in developed countries (Ahmed \& Duellman, 2007; Garcia Lara et al. 2007; Cullinan et al. 2012) rather than in developing countries, such as Egypt. More specifically, Egypt has a number of economic and market advantages, including (i) the most attractive market in terms of attracting foreign investment (EGX, 2011); (ii) one of the largest economies; (iii) one of the largest stock markets in terms of listed firms and market capitalisation; (iv) the most active and liquid stock market in terms of 
trading value and turnover; and (v) is the largest country in the Middle East and North Africa (MENA) region in terms of population. Despite these economic developments the CG practices are generally weak in Egypt, urgently requiring improvement in terms of implementation provisions relating to disclosure. Specifically, there is the need to enhance efficiency and transparency relating to financial and non-financial reporting and disclosures, which are critical to the ability to attract foreign direct investments (FDIs) in Egypt. Second, the late development of good CG practices and reforms, including CG codes, reflects the weak legal systems prevalent in most developing countries (Samaha et al., 2012). For example, the first formal Egyptian good CG code was only introduced in 2005 and the latest in 2011. By contrast, such CG reforms began as early as in the late 1970s, early 1980s, and 1990s in Hong Kong, the US and the UK, respectively, for example.

Consequently, this paper seeks to contribute to the previous literature in three main ways. First, to the best of our knowledge, it provides the first empirical evidence between CG mechanisms and accounting conservatism in the MENA region. This extends existing evidence to Egypt in particular, but the MENA region in general. Second, it suggests that in weak CG and investorprotection countries like Egypt, accounting conservatism appears to be a substitute for good governance. Third, it contributes to the literature by offering policy-makers and regulators in Egypt suggestions relating to how they may improve $\mathrm{CG}$ practices in corporations.

The rest of the paper is structured as follows. Section 2 outlines CG reforms and financial reporting challenges within the Egyptian context. Section 3 discusses CG and accounting conservatism within Egypt. While section 4 outlines the theoretical framework, section 5 reviews the relevant literature and develops the hypotheses. Section 6 discusses the research design and section 7 presents the empirical analyses and findings. Section 8 presents a brief summary, conclusion and potential avenues for future research.

\section{Corporate Governance reforms and financial reporting challenges within the Egyptian context:}

In Egypt, two domestic laws govern the companies that are listed in the Egyptian stock exchange. The first is one is the Capital Market Law (CML) (No. 95/1992) that defines the rules of listing and de-listing of companies, and regulates the financial market in terms of issuance and stock exchanges in Egypt. The second one is the Central Depository Law (CDL) (No. 93 /2000) that eliminates risks associated with trading securities in the sense of clearing and settlement (ROSC, 2001; Elsaman \& Alshorbagy, 2011). The Egyptian law system is primarily influenced by civil law; nevertheless, the Anglo-American common law concepts are well established in capital market and central depositary laws (Elsayed, 2010; Wahba, 2015). As a result, it can be argued that the legal system in Egypt is a blend of common and civil laws.

The need for initiation of CG codes in Egypt was clearly significant as the previous studies suggested that countries with civil law suffer from weakness in their legal framework (Fawzy, 2004). Furthermore, globalisation and international pressures from developed countries towards development of CG codes in developing countries increased (Reed, 2002). 
Egypt commenced CG reforms in 2001 when, with assistance from the IMF the World Bank conducted country assessment under the Report on the observance of standards and codes (ROSC) initiative. This ROSC benchmarked Egypt's CG practices against the OECD principles of corporate governance. The results indicated that Egyptian listed companies applied only $62 \%$ of the OECD principles (ROSC, 2001). In addition, this report highlighted the areas that need strengthening within the Egyptian CG system. These areas included the need to increase disclosure of ownership and control structures and financial and non-financial information, and emphasise the role of shareholder meetings, board of directors, and professional conduct of auditors. Consequently, in 2002, Egypt started to set out rules that maintain the implementation of $\mathrm{CG}$ practices. For instance, the Egyptian Stock Exchange (EGX) issued rules that require listed companies to undertake full disclosure and presentation about the company`s board members, and contracts with auditors and audit committees. But every action has a consequence as implementing such strict rules led to the de-listing of about 100 companies in the EGX (ROSC, 2004).

CG practices continued to improve. In 2003, in a joint project with the World Bank (WB), International Financial Corporation (IFC), and the United Nations (UN), the Egyptian government established the Egyptian Institute of Directors (EIoD). The EIoD was the first institute to focus on CG issues through spreading awareness to improve CG practices in Egypt. Consequently in 2005, the Ministry of Investment and the EIoD established the first voluntary Egyptian Code of CG. The provisions in this code were considered as a supplement to the above-mentioned Egyptian corporation laws, After the ROSC (2009) recommendations, the EIoD issued the next and final CG code in 2011 (i.e. after five years and not on an annual basis) and this is considered the current version.

CG and financial reporting in Egypt face many challenges. Firstly, the Egyptian CG code issued is based on the "comply or explain" approach, meaning that it is not compulsory for listed firms to comply. Thus, in the case of compliance, the companies should disclose how they apply these codes and, in the case of non-compliance the companies should explain why they did not comply with these codes. Although the voluntary compliance regime offers the opportunity for companies to justify why they did not comply with this provision and defend their situation, the disclosed reason for noncompliance may not be reasonable. Moreover, in the case of different characteristics between firms, this approach gives flexibility for companies to fit with appropriate codes (MacNeil \& Li, 2006; Al-Bassam $\&$ Ntim, 2017). However, the challenge was that, in the case of non-compliance, the companies used this option inadequately since the companies defend their non-compliance for spurious reasons that subsequently raise the problem of how non-compliance is monitored (MacNeil \& Li, 2006; Arcot et al., 2010; Nerantzidis, 2015). Using a sample of Greek listed firms based on the 'comply or explain' approach, Nerantzidis (2015) found that only 35\% comply with code provisions and that, among the non-compliance firms, only $59 \%$ provide explanations. Furthermore, by investigating CG practices in Egypt, Sorour (2014) has argued that most Egyptian firms symbolically comply with the CG provisions in order to achieve legitimacy. Therefore, the issuance of CG codes does not appear to aim at achieving efficiency and, therefore, compliance, implementation and enforcement are difficult. 
Secondly, the code also required all listed companies to disclose non-financial information such as board of directors' structure and its committees, ownership structure, and executive remuneration policies - along with financial information in their annual reports. However, the study sample indicates that only $35 \%$ provide CG statements on their websites. One of the reasons behind this failure was that there is no one integrated authority responsible for supervising the implementation of code provisions and enhance CG disclosures (Sorour, 2014). In addition, Egyptian CG code guidelines are partially voluntary as the provisions in this code act as a supplement to mandatory corporate laws which makes it difficult to audit and monitor such information to maintain transparency. Consequently, there is an inability to check the accuracy of information provided.

Finally, the Egyptian code recommended that the CG disclosure reports should be in both English and Arabic languages to enable investors and stakeholders to understand the report regardless of their nationalities (ECOCG, 2011). However, all listed companies on the EGX -100 that disclosed such information did so in the Arabic language only, which minimised the opportunity for foreign investment within the Egyptian context.

\section{Corporate governance and accounting conservatism within Egyptian context}

Egyptian CG reforms took place as recently as 2005, followed by the issuance of another code in 2006, with the most recent in 2011. Egypt is influenced by civil laws characterised by a weak legal framework that cannot protect stakeholders' rights, resulting in weak investor protection (Samaha $e t$ al., 2012). Alternatively, Anglo-American countries (i.e. the USA, the UK) have dispersed ownership among a wide range of shareholders (Epstein et al., 2012). This separation removes control from shareholders and promotes agency conflict (Letza et al., 2004). Accordingly, under the AngloAmerican CG system, the corporate board must have a large number of independent directors with no financial interest in the firm. On the other hand, in emerging markets such as Egypt, ownership is concentrated among government and/or founding families (Wahba, 2015), possibly resulting in collusion and weakening of the rights of minority shareholders to access company information. However, the non-separation of ownership and control results in reducing agency costs. In short, Egypt has a weak governance system reflected in the later issuing of CG codes.

Conservatism is a significant qualitative characteristic of financial accounting (Chi et al., 2009). Accounting conservatism is defined by Ruch and Taylor (2015, p.20) as "the tendency towards using policies and methods to understate the value of net assets with relation to their net economic value”. Another way, García Lara et al. (2007) define conservatism as a prudent reaction towards uncertainty that requires a higher level of verification and guarantee when recognising profits than when declaring losses.

According to Watts (2003a), accounting conservatism plays a vital role in restraining managers' overcompensation plans. The separation between managers and shareholders and their information asymmetry induces managers to overcompensate themselves. They are likely to have access to information such as future cash flows, which can be used to overstate current earnings. Thus, 
applying the concept of accounting conservatism (i.e. verification of good news) will restrict managers' opportunities to manipulate earnings (Ahmed \& Duellman, 2007).

Ball and Shaivakumar (2005) and Watts (2003a) argue that conservatism facilitates CG. Because it requires recognition of losses over gains, in the case of negative net present value (NPV) projects, timely recognition will signal the board of directors to investigate these projects and question managers. However, in terms of prior benefits provided by accounting conservatism, setters of standards do not include conservatism (prudence) as a qualitative aspect of faithful representation (FASB, 2010). The Financial Accounting Standards Board (FASB) justifies their exclusion of conservatism as a hindrance to neutrality. Similarly, Gigler et al. (2009) note that accounting conservatism results in inefficient markets. However, Tracey (2015) contends that conservatism is already unconsciously included in most accounting standards (i.e. the basic principle of revenue recognition that goods need to be transferred before the profit is recognised).

CG and accounting conservatism are closely related (Lim, 2011). CG is defined as a set of mechanisms that ensure a firm's assets are managed in an efficient way (Shleifer and Vishny, 1997), since CG mechanisms are a tool to maintain the implementation of accounting conservatism and reduce agency conflict. This implies that the existence of stronger CG mechanisms results in better monitoring of managers and thus higher demand for accounting conservatism. Lobo and Zhou (2006) contend that the incidence of accounting conservatism increases after the implementation of the Sarbanes-Oxley (SOX) Act provisions.

Another strand of discourse posits that CG mechanisms and accounting conservatism are substitutes; in the absence of strong CG mechanisms (as in civil law settings), managers tend to be conservative in their reporting in order to compensate for the weakness of the governance system. Therefore, conservatism acts as a substitute policy in reducing agency problems. Similarly, Lafond and Roychowdhury (2008) report a negative relationship between managerial ownership and accounting conservatism, arguing that demand for conservative reporting comes from shareholders. Citing Taiwanese firms, Chi et al. (2009) note that weak CG mechanisms are positively associated with high levels of accounting conservatism, implying that in weak civil law settings such conservatism acts as a substitute for CG mechanisms.

Given the governance practices in Egypt, this paper investigates the effect of CG attributes on the level of accounting conservatism, focusing on four mechanisms: board size, board independence, separation of chairman and CEO roles, and whether the auditor is one of the big four - $\mathrm{EY}, \mathrm{PwC}$, Deloitte and KPMG. The level of accounting conservatism is measured following Givoly and Hayn's (2000) popular approach (Ahmed \& Duellman, 2007; Ahmed \& Henry 2012; Elshandidy \& Hassanein, 2014). We examine a sample of 63 Egyptian firms over three years.

\section{Theoretical literature}

A small number of theories explain the relationship between CG and financial reporting quality (e.g., agency, stewardship and signalling theories), although previous studies (Beekes et al., 
2004; Ahmed \& Duellman, 2007; Ahmed \& Henry, 2012; Ntim, 2013a, b, c) identify the most commonly used agency and stewardship theories.

\section{Agency Theory}

Agency theory is dominant in CG literature (Daily et al., 2003; Clarke, 2007; Tunyi and Ntim, 2016). The agency relationship was defined by Jensen and Meckling (1976, p.308) as "a contract under which one or more persons (the principal(s)) engage another person (the agent) to perform some service on their behalf which involves delegating some decision making authority to the agent". Agency theory has two premises. The first is self-interest where that each person will act to maximise his or her interests against those of the other person's (Eisenhardt, 1989). However, Clarke (2007) argues that there is also the manager's competency, a factor in assessing decisions made by the agent. The second premise is that the capability to accept risk varies between shareholders and managers (risk aversion) (Eisenhardt, 1989). According to Jensen and Meckling (1976), reducing the divergence of interest between shareholders and managers requires appropriate control mechanisms.

However, agency theory has a limitation, in that it focuses on basic control structure (i.e. managers and shareholders) but ignores the "double agency problem" (Clarke, 2007): in large companies, boards of directors act on behalf of shareholders and monitor management; therefore, ignoring the role of the board of directors as a control mechanism is considered a failure of agency theory.

\section{Stewardship Theory}

Stewardship theory posits that managers' personal incentives are eliminated, and they act as good stewards of company assets; therefore, goal conflicts between management and shareholders end and no agency cost is incurred. Stewardship theory is underpinned by assumptions regarding the behaviour of managers. First, managers are blamed for corporate failure, so they act in a manner that results in superior performance (Donaldson \& Davis, 1991). Secondly, a manager's objectives are achieved through maximisation of shareholders' wealth, as shareholders will compensate managers for this (Davis et al., 1997). Thirdly, concerning CG, better performance is accompanied with inside directors, as they have better knowledge about the company than outside directors have (Kiel \& Nicholson, 2003). Thus, combining the roles of chairman and CEO will boost company performance. In sum, the proponents of stewardship theory argue that there is no inherited conflict between managers and shareholders, so managers do not need external oversight mechanisms to control their behaviour, and they act in a conservative manner.

\section{Literature review and hypothesis development}

\subsection{Relationship between $C G$ attributes and accounting conservatism}

Empirically, investigating how CG aspects affect the incidence of conservative accounting needs further investigation (Beekes et al., 2004; Ahmed \& Duellman, 2007; García Lara et al., 2007; 
Lim, 2011; Ahmed \& Henry, 2012; Elshandidy \& Hassanein, 2014; Caskey \& Laux, 2016). Table 1 summarises the results of previous studies; and two important factors emerge from these. First, the results are inconclusive, particularly across countries. Ahmed and Duellman (2007) investigated how board size, insiders on the board, and separation between chairman and CEO roles affect the incidence of conservative accounting in US firms, concluding that the percentage of insiders and accounting conservatism are negatively correlated. Meanwhile, there was no relation between other CG aspects and accounting conservatism. In contrast, using a sample of Australian listed firms, Ahmed and Henry (2014) contended that all CG attributes have a positive effect on accounting conservatism. Secondly, most of these studies were conducted in common law countries such as the UK, the US and Australia, with only two conducted in a civil law setting, Spain and Taiwan (see Table 1), and no study undertaken in emerging countries.

Concerning the CG dimensions examined here, three common internal dimensions used in previous studies are selected: board size, board independence, and separation between chairman and CEO (see Table 1). However, there was a lack of CG data for Egypt, we collected our CG data from The Disclosure Form for Boards of Directors which only showed board characteristics within Egyptian firms. Therefore, board characteristics can only examined. On the other hand, according to Lara et al. (2009), the success of CG dimensions in implementing conservatism is based on good coordination between internal and external mechanisms. As a result, and in line with Lim's (2011) study, auditor type is added as an external CG mechanism. In other words, the level of accounting conservatism provided by the Big 4 audit firms is higher than other audit firms as they are exposed to public scrutiny. As a result it is important to examine such relationships.

\section{[Insert Table 1 about here]}

\subsection{Hypothesis Development}

The theoretical and empirical nexus for each CG mechanism, with any recommendations from Egyptian code, are highlighted and a hypothesis for each mechanism is developed.

\section{Board Size and Accounting Conservatism}

Board size is a common board structure variable in governance literature: many studies have investigated the relationship between board size and accounting conservatism. (e.g., Beekes et al., 2004; Ahmed \& Henry, 2012; Kukah et al., 2016). There is debate concerning the appropriate size of the board, and the number of members varies depending on countries' CG code recommendations, offering no consensus.

Theoretically, there are two opposing views regarding board size (Ntim, 2016). In line with agency theory, a small board is preferred because a large board is associated with communication issues, disputes among members, and slowing the flow of decisions (Lipton \& Lorsch 1992; Jensen, 1993). A large board size results in "free rider" problems: if there is a large number of members, each depends on the others when monitoring management (Hermlin \& Weibach, 2003). On the other hand, 
a large board enhances effectiveness in terms of the monitoring process, boosting the incidence of conservative accounting because board diversity in terms of expertise - particularly financial reporting - may be increased (Ebrahim \& Fattah, 2015). Ahmed and Duellman (2007) argue that in a large board, a manager`s decisions are subject to a greater level of inspection from more directors.

Empirically, the results are inconclusive, although a small number of board members may demand more accounting conservatism (e.g., Beasley, 1996; Chi et al., 2009). Beasley (1996) reported a negative correlation between board size and financial statement fraud. Similarly, using a sample of Taiwanese companies, Chi et al. (2009) found that a large board demands less conservative accounting. They contended that a small board is considered as a poor governance mechanism, and as a result its members act more conservatively to compensate for this weakness. In contrast, with 120 listed Australian companies over 11 years, Ahmed and Henry (2012) reported that a larger board size increases the extent of understatement of earnings and book values, which in turn results in more conservative accounting.

A second strand of empirical findings suggests that board size has no significant effect on accounting conservatism. Using a sample of 200 listed US companies over a three-year accounting period, Ahmed and Duellman (2007) reported no significant association. Similarly, with 100 UK firms on the FTSE index over a six-year period, Elshandidy and Hassanein (2014) failed to find a significant relationship between board size and accounting conservatism.

In practice, the latest Egyptian CG code specified that board size should consist of no fewer than five members (ECOCG, 2011). Given the mixed empirical evidence in previous studies and recommendation from code, we test the following hypothesis:

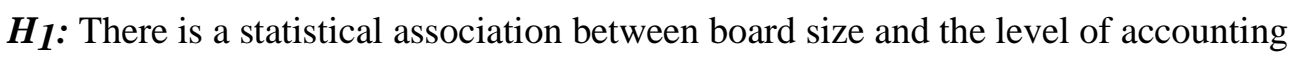
conservatism in Egyptian companies.

\section{Board Independence and Accounting Conservatism}

Independent (outside) directors are considered one of the most effective internal CG mechanisms (Lim, 2011; Haque \& Ntim, 2017). Theoretically, there are two competing views: one supporting and the other opposing agency theory.

In line with agency theory, the existence of independent directors helps to reduce agency conflicts that arise from a separation between shareholders and managers, through effective monitoring of managers' behaviour (Jensen \& Meckling, 1976; Fama, 1980). As managers tend to overstate earnings to overcompensate themselves (Watts \& Zimmerman, 1986; Lim, 2011), the presence of independent directors is likely to curb this behaviour through effective monitoring. Hazarika et al. (2012) also found a positive relationship between a manager's turnover and earnings management, and Beekes et al. (2004) suggested that external directors have experience of the financial reporting process from acting as senior managers in other corporations, enhancing accounting quality, and understanding the importance of applying conservatism through reporting.

Cash-based remuneration, the usual method for outside directors, could also be an incentive 
for inside directors to be less conservative in their reporting (Ahmed \& Henry, 2012). However, for inside (executive) directors, this amounts to stock options or bonus shares, which are based on accounting numbers and can be easily manipulated (Beekes et al., 2004), inducing them to be less conservative in financial reporting.

On the other hand, the proponents of stewardship theory suggest that the appointment of outside directors has drawbacks. Weir and Laing (2000) noted that outside directors are frequently employed on a part-time basis and hold jobs with other companies. Thus, they encounter difficulties in comprehending the complexity of companies, which in turn has an adverse effect on their monitoring tasks. In contrast, inside directors have access to more information, resulting in high-quality decision making (Klein, 1998; Nicholson \& Kiel, 2007).

Empirically, there are two sets of empirical evidence regarding board independence and accounting conservatism. The first suggests that a high proportion of outside directors has a positive impact on accounting conservatism. Beekes et al. (2004) reported a positive relationship between the percentage of outside directors and conservatism, justifying their reasoning by noting that a higher proportion of non-executive directors enabled them to monitor management activities and influence conservatism more effectively. Using a sample of Ghanaian firms, Kukah et al. (2016) lent support to Beekes' findings that board independence constrains managers' opportunities to manipulate earnings and thus be more conservative. These results lend support to agency theory.

In contrast, the second set states that there is no significant relationship between board independence and accounting conservatism. From a sample of 644 and 774 Australian firms in 1998 and 2002 respectively, Lim (2011) concluded that the percentage of independent directors was weakly associated with the incidence of conservative accounting, explaining this by the effect of different institutional settings between Australian and non-Australian firms. Similarly, with a sample of Spanish firms, García Lara et al. (2007) reported no significant effect of independent directors on the level of accounting conservatism.

In practice, Egypt follows the same assumption that a high number of outsiders on the board acts as a strong CG mechanism. The latest Egyptian CG code suggested that the majority should be non-executive directors (ECOCG, 2011). Given the empirical evidence and recommendation, the proposed hypothesis is as follows:

$H_{2}$ : There is a significant positive relationship between board independence and the level of accounting conservatism in Egyptian companies. 


\section{Separation of Chairman and CEO roles and Accounting Conservatism}

When the CEO is also chairman of the board, this is referred to as CEO duality. There are two conflicting views; agency theory supporting the separation of the roles and stewardship theory supporting CEO duality (Ntim, 2012). According to agency theory, CEO duality is unadvisable as it weakens the monitoring process and increases agency conflict and information asymmetry, and is thus considered a weak governance mechanism (Chi et al., 2009). The chairman's responsibilities comprise hiring, firing, monitoring and evaluating the CEO's performance (Jensen, 1993; Dey et al., 2011), while the CEO is responsible for running the company's activities on a daily basis. Therefore, if the CEO is also the chairman, the CEO's performance cannot be assessed, making it difficult to remove an incompetent CEO. Lincoln et al. (2013) agree that when the roles are separated it is easier to identify who is responsible for bad performance or decision making (i.e. more conservatism).

On the other hand, stewardship theory supports CEO duality because, according to Finkelstein and D'Aveni (1994), duality reduces internal conflict and minimises board interference as it provides unified board leadership (unity of command). Consistent with this view, Brickely et al. (1997) argued that the cost of separation of the roles of chairman and CEO outweighs its benefits: costs include transferring information between a CEO and chairman, and compensation fees for an outside chairman. Weir et al. (2002) suggested that insiders such as the CEO have a better understanding of the strengths and weaknesses of a company's operation than outsiders have, which facilitates decision making.

The empirical evidence is mixed. One strand of studies found a positive relationship between the separation of roles and accounting conservatism (e.g., García Lara et al., 2007; Lim, 2011; Elshandidy \& Hassanein, 2014). A second strand centres on the work of Chi et al. (2009): using a sample of 4,181 Taiwanese firms' observations from 1996 to 2004, they reported that firms with CEO duality tended to be conservative in their reporting. They argued that CEO duality is a weak CG mechanism, so once a CEO becomes chairman, he/she tends to be conservative to compensate for this weakness.

A third strand of evidence posits that CEO duality has no influence on accounting conservatism. Using a sample of US firms, Ahmed and Duellman (2007) argued that there is an insignificant relationship between CEO duality and accounting conservatism. Elsayed (2010) investigated the board leadership structure including CEO duality and non-duality within Egyptian firms, concluding that the concept of CEO duality is widespread among Egyptian firms and has no impact on performance in Egyptian companies.

The 2011 Egyptian CG code did not offer any information concerning CEO duality (ECOCG, 2011). Given the mixed empirical evidence from previous studies and recommendations, the hypothesis tested is:

H3: There is a statistical association between separation of chairman and CEO roles and the level 
of accounting conservatism in Egyptian companies.

\section{Auditor Type and Accounting conservatism}

From the theoretical perspective, The "Big 4" auditors are considered as a substitute for external CG mechanisms (Gillan, 2006; Khurana \& Raman, 2004). According to agency theory, the separation of shareholders and managers requires a third party to provide assurances and increase investor confidence regarding financial statements and implementation of accounting standards. Khurana and Raman (2004) stated that big audit firms provide more assurance and credibility regarding financial statements than smaller ones do.

Similarly, the level of credibility and conservatism provided by the Big 4 audit firms is higher, because they are exposed to public scrutiny and reputational risk (Kim et al., 2003); they therefore prefer conservative accounting choices to protect themselves (Khurana \& Raman, 2004). Also, the big audit firms are more exposed to client litigation risk, meaning larger damage awards from lawsuits. Another argument, though, suggests that the audit quality of the Big 4 varies according to the investor protection regime and oversight mechanisms. Francis and Wang (2008) examined the joint effect of earnings quality (i.e. reporting loss and conservatism) and the Big 4 over 42 countries, concluding that earnings quality is enhanced by strong investor protection, but only for firms audited by one of the Big 4. This implies that in the weak investor-protection systems of emerging countries, low earnings and poor audit quality are associated with the Big 4 auditors.

Empirically, a strand of studies shows that the extent of earnings management decreases with the Big 4 (Becker et al., 1998; Chung et al., 2003; Cano-Rodriguez, 2010; Mitra et al., 2016), subsequently improving accounting quality. More specifically, Chung et al. (2003) found that the Big 4 auditors force their clients to be more conservative than do smaller audit firms. Mitra et al. (2016) argued that US firms switching from the Big 4 to smaller auditors exhibit less accounting conservatism. However, of central importance to our research context, is that in a study of Turkish companies (emerging markets), Yaşar (2013) suggested that there is no difference between big and non-big auditors in terms of curbing earnings management. Given the mixed empirical evidence in the previous studies, the hypothesis tested is:

H4: There is a statistical association between the Big 4 auditors and the level of accounting conservatism in Egyptian firms.

\section{Research Design}

\subsection{Data and sample consideration}

The EGX-100 index was chosen as proxy for the Egyptian context. The reasons for choosing the EGX-100 index is because it includes the 100 most active firms in the Egyptian context according to their capital size and level of conservatism (Samaha et al., 2010), and also includes the 30 constituent companies of the EGX-30 index and the 70 constituent companies of the EGX-70 index. 
Thus, it is assumed that all these companies that are listed on this index have good governance and reporting practices.

All the EGX-100 companies at the end of 2015were considered. In order to obtain a more detailed analysis, and in line with previous studies (e.g., Ntim, 2009; Elshandidy \& Hassanein, 2014), they were classified into 10 major industries according to the Industry Classification Benchmarks (ICB), but excluding financial and utility firms because of their different governance structure (Guest, 2009). Elshandidy and Hassanein (2014) suggested that financial firms adopt specific regulations that may affect their level of conservatism, and that excluding them facilitates comparison with previous studies. Other companies whose financial and/or governance data were not found were also excluded, resulting in a final sample of 67 firms, as shown in Panel A in Table 2.

Panel B in Table 2 also presents the industrial composition for the sample, showing specific combinations of different industries, which will strengthen the results. This research only covers three years, from 2011 to 2013, because the CG data collected from The Disclosure Form for Boards of Directors were only required by the Egyptian government for EGX listed companies from 2011. This nevertheless meets the requirement of the accounting conservatism measure to cover at least three years. The final sample thus comprises a total of 201 Egyptian observations.

Two main types of data were collected. First, data for CG variables board size, percentage of non-executive directors, separation of chairman/CEO roles and auditor type were hand-collected from companies' annual reports. Second, the financial data required to calculate accounting conservatism were extracted from the Osiris database.

\section{Insert Table 2 about here}

\subsection{Variables and measures}

\section{Dependent variable}

To test $\mathrm{H} 1$ to $\mathrm{H} 4$, the dependent variable is accounting conservatism. In accounting literature, the most commonly used measurements are Basu's (1997) model and the accrual-based measure of Givoly and Hayn's (2000) model. Basu's model has been criticised as it requires many numbers and might result in biased estimates (Dietrich et al., 2007). However, the Givoly and Hayn model is an accounting-based measure in all of its aspects and thus facilitates calculations based on published financial statements. Therefore, following the Givoly and Hayn model, accounting conservatism is equal to net income before extraordinary items plus depreciation expense less cash flow from operating activities averaged over a three-year period and total assets; the outcome is multiplied by -1 to remove the effect of large accruals. Thus, Equation (1) is as follows:

$$
\text { CONS } i t=\left(I B E X T_{i t}+D P_{i t}-C F O \text { it }\right) X-1,
$$

where CONS it refers to accounting conservatism in firm $i$ and year $t, I B E X T$ it to net income before extraordinary items, $D E P$ it to depreciation expense and $C F O$ it to cash flow from operating 
activities. If the result from Equation (1) is positive, this means that more accounting conservatism was reported; and if negative, companies tend to be less conservative about their reporting.

\section{The independent and control variables}

The independent variables for assessing CG effect on accounting conservatism are board size (BSIZE), board independence (\%NXD), separation of chairman/CEO roles ( $S / C E O D)$, and auditor type $(A U D T)$. As accounting conservatism is essentially a managerial attitude, it can be influenced by several factors (Elshandidy \& Hassanein, 2014). Also, to avoid the potential bias of omitted variables (Gujarati, 2015), four other variables are added as control variables, following previous studies (Ahmed \& Duellman, 2007; Chi et al., 2009; Cullinan et al., 2012): firm size (FSIZE), profitability (PROF), leverage (LEV) and sales growth (SALESGR). With regard to firm's size, Lim (2011) noted that firm size is sensitive and positively associated with accounting conservatism. This is because the larger firms tend to be more conservative about their reporting than smaller firms are, due to public scrutiny. Table 3 summarises these measurements.

\section{[Insert Table 3 about here]}

\section{Empirical model}

In order to achieve the objectives of this study and to test the hypotheses, this research follows previous studies (Ahmed \& Duellman, 2007; García Lara et al., 2007; Chi et al., 2009; Lim 2011; Ahmed \& Henry, 2012) in using a multiple regression model to examine the effect of CG mechanisms on the incidence of accounting conservatism. Aggregating the dependent, independent and control variables, the model is as follows:

Model 1

$$
\begin{gathered}
\text { CONS it }=\beta 0+\beta 1 B S I Z E i, t+\beta 2 N X D i, t+\beta 3 \text { S/CEOD } i, t+\beta 4 A U D T i, t+\beta 5 F S I Z E i, t+\beta 6 \\
P R O F i, t+\beta 7 L E V i, t+\beta 8 \text { SALESGR } i, t+\varepsilon i, t,
\end{gathered}
$$

where CONS it $=$ accounting conservatism measured using Equation (1), and for

firm $i$ in year $t$

BSIZE $_{\text {it }}=$ board size;

$N X D_{i t}=$ percentage of non-executive directors;

$\mathrm{S} / \mathrm{CEOD}=$ separation of chairman/CEO roles;

$A U D T_{i t}=$ auditor type FSIZE $_{i t}=$ firm size;

PROF $i t=$ profitability ratio;

$\mathrm{LEV}_{\text {it }}=$ leverage ratio;

SALESGR $i t=$ sales growth ratio;

$\varepsilon_{i, t}=$ error term for the model. 


\section{Empirical analysis and discussion}

\subsection{Descriptive statistics and correlation analysis}

The results in Table 4 show that the mean value of accounting conservatism (CONS) in Egypt is -0.018 , calculated as explained above (Equation (1)). The positive value indicates that companies tend to be more conservative in their financial reporting. By contrast, the negative value indicates a lower degree of accounting conservatism. The negative value reported by Egyptian companies is lower than that reported in the US and the UK (Ahmed \& Duellman, 2007; Elshandidy \& Hassanein, 2014). This indicates that Egypt reported the lowest degree of accounting conservatism compared to other countries.

For independent variables, the descriptive statistics for board size (BSIZE) show that the minimum number is three and the maximum number is 17 . Moreover, the average percentage of nonexecutive directors (NXD) on the board is $70 \%$. This result is consistent with the findings of Ahmed and Duellman's (2007) study and meets the recommendation for Egyptian code of CG that insist that at least $50 \%$ of the board should be non-executive. Panel $\mathrm{C}$ also shows that only $22 \%$ of Egyptian firms separate chairman and CEO positions, a lower percentage than that reported for US firms, $31 \%$ (Ahmed \& Duellman, 2007). The reason for the high percentage of CEO duality in Egypt is that there is no clear recommendation in the Egyptian CG code (2011) for separation. Panel C also shows that only $32 \%$ of Egyptian companies were audited by one of the Big 4.

In terms of control variables - the FSIZE, PROF, LEV and SALESGR, the mean values for those variables in both countries are only slightly consistent with the findings of Ahmed and Duellman's (2007) US study, and Wahba's (2015) Egyptian study.

\section{[Insert Table 4 about here]}

Table 5 reports the correlation matrix for all variables to test for multicollinearity. To ensure unbiased results, both Pearson parametric and Spearman's non-parametric coefficients are computed. Their results are similar and the bivariate correlations are averagely low, indicating no multicollinearity problem. For easier comparison with previous research the focus here is on Pearson's correlation. Table 5 shows that there is no significant relationship between board size or board independence with accounting conservatism ( $r=.019$, .064respectively), consistent with the findings of Elshandidy and Hassanein (2014) in the UK. However, there is evidence of weak positive correlation between accounting conservatism and separation of chairman/CEO roles $(r=.154$, $p<0.01)$. For control variables, firm size and leverage ratio are positively correlated with accounting conservatism at a significant level of $5 \%$ ( $r=.278, .281$ respectively). This indicates that largeleveraged firms tend to be more conservative in their reporting than low-leveraged firms are.

\section{[Insert Table 5 about here]}

\subsection{Multivariate regression analysis}


After validation of all regression assumptions, OLS regression is applied to the main empirical model. Table 6 contains the results of regression analysis of CG mechanisms on accounting conservatism in Egypt. The empirical model was first tested without control variables, using Model 1 (see Table 6). The adjusted $R^{2}$ was very weak $\left(R^{2}=-.009\right)$. However, after inclusion of the control variables in Model 2, the outcome changed slightly; the adjusted $R^{2}$ increasing to $\left(R^{2}=, .126\right) \cdot R^{2}$ of 0.126 in Model 2 means that $12.6 \%$ of variations in the dependent variable (accounting conservatism) are caused by independent variables. The values of $R^{2}$ for both models are similar to those reported in other studies (Ahmed \& Duellman, 2007; Elshandidy \& Hassanein, 2014).

\section{[Insert Table 6 about here]}

\section{Results and Discussion}

\section{Board Size and Accounting Conservatism}

Model 2 of Table 6 indicates a significant negative relationship between board size and accounting conservatism, thus $H_{l}$ is accepted. This finding disagrees with Ahmed and Henry (2012), who concluded that large board size enhanced the level of accounting conservatism in Australian firms, over an 11-year period. This inconsistency may arise from the large 11-year sample and different national governance practices, and Ahmed and Henry's use of four measures for accounting conservatism, including accounting and market-based measures.

On the other hand, with regard to common law countries, studies such as those by Ahmed and Duellman (2007) in the US, and Elshandidy and Hassanein (2014) in the UK reported no significant relationship between board size and accounting conservatism. This implies that, in general, board size has no impact on the incidence of accounting conservatism, particularly in common law countries characterised by strong investor protection.

For Egypt, a significant negative association was found between board size and accounting conservatism, consistent with Chi. et al.'s (2009) Taiwanese study, which reported that a large board size reduced the incidence of accounting conservatism. It also lends support to Beasley's (1996) findings which provide empirical evidence that large board size is associated with the likelihood of financial statement fraud.

Board size as a CG mechanism is not significantly associated with conservatism in common law countries like the US and the UK, as they have strong investor protection. However, civil law countries like Egypt and Taiwan have poor investor protection and weak governance systems, so accounting conservatism acts as a substitute for CG mechanisms. In other words, as small board size is considered a weak CG mechanism, managers tend to be conservative in their reporting to compensate for this. 


\section{Board Independence and Accounting Conservatism}

As shown in Table 6, Model 2 indicates a significant positive relationship between board independence and accounting conservatism; thus $H_{2}$ is accepted. This finding supports recommendations from the latest Egyptian CG code that insist on a majority of outside directors. Empirically, these findings are consistent with those of Beekes et al. (2004), Ahmed and Duellman (2007), Ahmed and Henry (2012) and Kukah et al. (2016) that boards with higher percentages of outside directors tend to demand more conservative accounting. Our findings also lend support to Xie et al. (2003), who found a negative association between the proportion of independent directors and earnings management.

However, our findings are inconsistent with Lim's (2011) study, which found a weak association between the percentage of independent directors and accounting conservatism. This inconsistency may be because of national differences in institutional settings and accounting disclosure systems. Another possible explanation is that Lim's study used another proxy for measuring board independence, according to the Australian CG code.

Our results further support agency theory, which suggests that more independent directors are more likely to use accounting conservatism as a tool for reducing agency conflict and facilitating the monitoring process over managers. Therefore, the fewer non-executive directors there are on the board, the less accounting conservatism will be exhibited.

Overall, comparing our results with previous findings, it can be argued that non-executive directors are positively associated with accounting conservatism in different contexts (the UK, Egypt, the US, Ghana, Australia). Therefore, these results strongly suggest that the existence of non-executive directors in both common (strong investor protection) and civil law (weak investor protection) countries is considered an effective mechanism that enhances the level of accounting conservatism.

\section{CEO Duality and Accounting Conservatism}

Model 2 of Table 6 indicates a negative but insignificant relationship between the separation of chairman and CEO roles, and accounting conservatism in Egyptian firms; thus $H_{3}$ was rejected.The Egyptian result shows that separation of the chairman and CEO roles has an insignificant negative effect on the incidence of conservatism. This is consistent with another civil law country (Taiwan) as reported by Chi et al. (2007); as the CEO becomes chairman, the level of conservatism is increased. This supports the stewardship theory, which suggests that combining the roles of chairman and CEO enhances the level of a firm's performance and makes managers more conservative in their reporting.

On the other hand, this finding is inconsistent with the findings of a recent UK study by Elshandidy and Hassanein (2014), and García et al.'s (2007) Spanish study, which reported that separation increased the incidence of accounting conservatism. It also contradicts agency theory's suggestion that CEO duality encourages agency problems because of the board's weakness in monitoring the CEO. Separating the two positions will enhance board independence and thus restrict aggressive reporting decisions. 
The inconsistency in results may be due to poor CG practices in Egypt. For instance, the latest Egyptian CG code (2011) did not comment on CEO duality, so managers tend to be conservative in their reporting to compensate for this weakness in the governance system. Overall, separation between chairman and CEO roles in Anglo-American countries appears to be considered an effective mechanism for increasing accounting conservatism. However, in emerging countries (Egypt) characterised by weak governance practices, accounting conservatism may be considered a compensatory mechanism in reducing agency conflict.

\section{Auditor Type and Accounting Conservatism}

Model 2 of Table 6 indicates a significant negative relationship reported with $H_{4}$. This result reveals that when Egyptian firms decide to be audited by one of the Big 4, they tend to be less conservative in their reporting. This result disagrees with the findings of Lim (2011), who suggested that the extent of conservatism varies with companies audited by the Big 4 , based on a sample of Australian firms. However, this positive association lasted for only one year (2002) of the sample period (1998-2002) due to the collapse of the Big 4 from 1998 to 2001. Our findings also conflict with Chung et al.'s (2003) study, which suggests that the level of accounting conservatism is enhanced in companies audited by big audit firms. However, there was a weakness in this study; that this positive relationship is valid only in one circumstance, which is if the client's current financial performance is better than expected.

On the other hand, the negative association between the Big 4 and accounting conservatism in Egyptian firms supports the argument that the audit quality of the Big 4 depends on the investor protection regime (Francis \& Wang, 2008; Mitra et al., 2016). Big 4 auditors are more likely to enhance reporting quality in strong investor protection regimes due to high litigation risk and strong oversight mechanisms. Therefore, in weak protection regimes, audit quality cannot be controlled. Samaha et al. (2010) similarly suggest that weakness of control mechanisms dealing with noncompliance with accounting and auditing standards leads to a reduction in the level of audit quality in Egyptian firms. Another possible explanation for this negative association is that as the Big 4 have a good reputation worldwide, in the case of low public scrutiny (as in Egypt) they are not concerned with maintaining accounting conservatism during audit. In contrast, non-big auditors act to improve their audit quality and maintain the concept of accounting conservatism. The empirical evidence from Egyptian firms also supports a recent emerging market study by Yasar (2013), who argues that there is no difference between audit quality for big and non-big audit firms in curbing earnings management in Turkey. 


\subsection{Additional analysis}

As a sensitivity check, the main empirical model was subjected to fixed effects (FE) regression (fixing year and firm-specific factors), as shown in Model 3 of Table 6. FE regression is superior to OLS regression as it can control unobservable factors (Gujarati \& Porter, 2009). For instance, in our study, an unobservable factor is firm heterogeneity (company-level differences) that might be correlated with the dependent variable (accounting conservatism), and thus the results might be slightly biased.

FE regression results bring important conclusion. The significance of some CG variables with accounting conservatism is removed; for example, board size (see Model 3 in Table 6). This might be because FE regression generates biased estimates if the independent variables fluctuate significantly between different firms but there is consistency over time within the same firm (Wooldridge, 2013). For instance, in our study, board size changes from one firm to another, but tends to remain stable over time within the same firm.

\section{Summary and Conclusion}

The effect of CG on the level of accounting conservatism has been investigated in a number of studies (Beekes et al. 2004; Ahmed \& Duellman 2007; Chi et al., 2009; Ahmed \& Henry 2012; Elshandidy \& Hassanein, 2014; Caskey \& Laux, 2016; Kukah et al., 2016), but the results are inconclusive. In our study, four main hypotheses were examined.

First, a negative association was found between board size and accounting conservatism in Egyptian firms. These results support Chi et al. (2009), who reported that a large board size reduces the level of accounting conservatism. This implies that in cases of small board size (weak governance mechanism as in Egypt), companies tend to be conservative in their reporting to compensate for the weak governance structure.

The second hypothesis proposed a positive association between board independence and the extent of conservative accounting. This result is consistent with the recommendation of the Egyptian CG code that the majority of directors should be outside directors. They also agree with the findings of Beekes et al. (2004), Ahmed and Duellman (2007), Ahmed and Henry (2012) and Kukah et al. (2016). These findings imply that board independence as a CG mechanism plays a powerful role in enhancing the level of accounting conservatism in most countries.

Moreover, there is a negative but insignificant relationship between the separation of roles and conservatism in Egyptian firms, probably because the most recent Egyptian CG code (2011) discloses no information related to the separation of chairman and CEO roles. Most Egyptian firms therefore have a dual leadership structure. This is consistent with the findings of Chi et al. (2009), that there is a positive association between CEO duality and accounting conservatism within Taiwanese firms. 
The fourth, and final, hypothesis anticipated a statistical association between auditor type and the extent of accounting conservatism. Surprisingly, a statistically significant negative relationship between the Big 4 and the extent of accounting conservatism was found within Egyptian firms, possibly because of the weaknesses of oversight mechanisms on auditors in Egypt. In summary, the study findings propose that effective CG mechanisms enhance the level of accounting conservatism. However, the poor governance system in Egypt encourages conservatism to act as a substitute for the weaknesses in the governance structure.

Limitations in this study might have a potential impact on the findings: these are sample and variables limitations. First, the study sample is based on companies listed in the EGX-100 index, bringing both advantages and disadvantages. For instance, selecting companies from the EGX-100 index resulted in a final sample of 67 firms, a large sample size compared to previous work in Egypt, such as Wahba's (2015) study of only 40 listed Egyptian companies that examined the effect of CEO duality on performance. However, the weakness of our selected sample is that it is not random, and focuses on companies with large capital; thus, the findings might be biased towards large firms and cannot be generalised to small or medium firms.

Secondly, regarding variables, previous studies (Beekes et al., 2004; Elshandidy \& Hassanein, 2014) were followed, using only one measure for accounting conservatism, despite other measures found, for example, in the Basu model. Again, the research focused only on the common governance attributes used in previous studies, ignoring other internal and external governance mechanisms such as ownership structure, internal control systems, and laws and regulations.

Thirdly, the endogeneity problem could not be statistically controlled: the direction of causality is from governance to conservatism or from conservatism to governance. Xia and Zhu (2009) argued that it is difficult to control the problem of endogeneity in the case of the four aspects of CG examined. However, most prior studies examining the CG accounting-conservatism relationship assumed the direction of causality to be from governance to conservatism (e.g., Ahmed \& Duellman, 2007; García et al., 2009; Lim, 2011).

To counteract these limitations, there are several future research avenues. Firstly, since the findings from developing countries such as Egypt are different, a wider cross-country study examining the association between CG mechanisms and the incidence of accounting conservatism might provide more insight into the nature of this relationship. Secondly, further research could examine the association between CG mechanisms and accounting conservatism by considering more internal and external CG mechanisms, such as block ownership structure and the market for corporate controls. These attributes may affect the incidence of accounting conservatism, along with using different measures for accounting conservatism, thereby strengthening the results.

Finally, the findings raise an important question which might be a potential avenue for future research: What are the determinants of accounting conservatism in terms of CG mechanisms? In other 
words, which of the CG mechanisms - internal or external - most affects the incidence of accounting conservatism?

\section{References}

Abdulrahman, M., Abdou, H., Ntim, C.G., and Elamer, A.A. (2017). Corporate boards, ownership structures and corporate disclosures: Evidence from a developing country. Journal of Applied Accounting Research, Forthcoming.

Aguilera, R. V., \& Cuervo-Cazurra, A. (2009). Codes of good governance. Corporate governance: an international review, Vol. 17 No. 3, pp.376-387.

Ahmed, A. S., \& Duellman, S. (2007). Accounting conservatism and board of director characteristics: An empirical analysis. Journal of accounting and economics, Vol. 43 No. 2, pp.411-437.

Ahmed, K., \& Henry, D. (2012). Accounting conservatism and voluntary corporate governance mechanisms by Australian firms. Accounting \& Finance, Vol.52 No.3, pp. 631- 662.

Al-Bassam, W.M. and Ntim, C.G. (2017). The effect of Islamic values on voluntary corporate governance disclosure: The case of Saudi listed firms. Journal of Islamic Accounting and Business Research, Vol. 8 No. 2, pp.182-202.

Aly, D., Simon, J., \&Hussainey, K. (2010). Determinants of corporate internet reporting: evidence from Egypt. Managerial Auditing Journal, Vol.25 No. 2, pp. 182-202.

Ball, R., \&Shivakumar, L. (2005). Earnings quality in UK private firms: comparative loss recognition timeliness. Journal of accounting and economics, Vol.39 No.1, pp. 83-128.

Basu, S. (1997). The conservatism principle and the asymmetric timeliness of earnings

1. Journal of accounting and economics, Vol.24 No.1, pp.3-37.

Beasley, M. S. (1996). An empirical analysis of the relation between the board of director composition and financial statement fraud. Accounting Review, Vol.71 No. 4, pp. 443-465.

Becker, C. L., Defond, M. L., Jiambalvo, J., \&Subramanyam, K. R. (1998). The effect of audit quality on earnings management. Contemporary Accounting Research, Vol.15 No. 1, pp. 1-24.

Beekes, W., Pope, P., \& Young, S. (2004). The link between earnings timeliness, earnings conservatism and board composition: Evidence from the UK. Corporate Governance: An International Review, Vol. 12 No. 1, pp. 47-59.

Brickley, J. A., Coles, J. L., \& Jarrell, G. (1997). Leadership structure: Separating the CEO and chairman of the board. Journal of corporate Finance, Vol. 3 No. 3, pp. 189-220.

Cano-Rodríguez, M. (2010). Big auditors, private firms and accounting conservatism: Spanish evidence. European Accounting Review, Vol. 19 No. 1, pp.131-159.

Caskey, J., \&Laux, V. (2016). Corporate governance, accounting conservatism, and manipulation. Management Science.Articles in Advance, pp. 1-14

Chi, W., Liu, C., \& Wang, T. (2009). What affects accounting conservatism: A corporate governance perspective.Journal of contemporary accounting \& economics, Vol.5 No.1, pp. 47-59.

Chung, R., Firth, M., \& Kim, J. B. (2003). Auditor conservatism and reported earnings. Accounting and Business Research, Vol.33 No.1, pp. 19-32.

Clarke, T. (2007). International corporate governance: A comparative approach (1st ed.). Routledge, London.

Coles, J. L., Daniel, N. D., \&Naveen, L. (2008). Boards: Does one size fit all?Journal of Financial Economics, Vol. 87 No.2, pp. 329-356.

Cullinan, C. P., Wang, F., Wang, P., \& Zhang, J. (2012). Ownership structure and accounting conservatism in China. Journal of International Accounting, Auditing and Taxation, Vol.21 No. 1, pp.1-16.

Daily, C. M., Dalton, D. R., \&Cannella, A. A. (2003). Corporate governance: Decades of dialogue and data. The Academy of Management Review, Vol. 28 No.3, pp.371-382.

Davis, J. H., Schoorman, F. D., \& Donaldson, L. (1997). Toward a stewardship theory of management. Academy of Management review, Vol. 22 No.1, pp.20-47.

DeFond, M. L., \&Subramanyam, K. R. (1998). Auditor changes and discretionary accruals. Journal of accounting and Economics, Vol. 25 No.1, pp. 35-67.

Dey, A., Engel, E., \& Liu, X. (2011). CEO and board chair roles: To split or not to split? Journal of Corporate Finance, Vol. 17 No.5, pp.1595-1618. 
Dietrich, J. R., Muller III, K. A., \&Riedl, E. J. (2007). Asymmetric timeliness tests of accounting conservatism. Review of Accounting Studies, Vol.12 No.1, pp. 95-124.

Donaldson, L., \& Davis, J. H. (1991). Stewardship theory or agency theory: CEO governance and shareholder returns. Australian Journal of management, Vol. 16 No.1, pp.49-64.

Ebrahim, A., \& Fattah, T. A. (2015). Corporate governance and initial compliance with IFRS in emerging markets: The case of income tax accounting in Egypt. Journal of International Accounting, Auditing and Taxation, Vol. 24, pp. 46-60.

Egypt Code of Corporate Governance (2005, 2011) -Egypt Code of Corporate Governance: Guideline and Standards\| available at: http://www.hawkama.net/files/toolkit/content/cgprogramspartners/Egyptian_Code_of_Corporat e Governance Guidelines andStandards October 2005 Egypt English.pdf. (accessed 1 October 2014)

Eisenhardt, K. M. (1989). Agency theory: An assessment and review. Academy of management review, Vol.14 No.1, pp. 57-74.

Elamer, A.A., Ntim, C.G. and Abdou, H. (2017). Islamic governance, national governance and risk management and disclosures practices in MENA countries. Business \& Society, Forthcoming.

Elghuweel, M.I., Ntim, C.G., Opong, K.K., and Avison, L. (2017). Corporate governance, Islamic governance and earnings management in Oman: New empirical insights from behavioural theoretical perspective. Journal of Accounting in Emerging Economies, Vol. 7 No. 2, pp.190224.

Elmagrhi, M.H., Ntim, C.G., and Wang, Y. (2016). Antecedents of voluntary corporate governance disclosure: A post-2007/08 financial crisis evidence from the influential UK Combined Code. Corporate Governance, Vol. 16 No. 3, pp.507-538.

Elmagrhi, M.H., Ntim, C.G., Crossley, R., Malagila, J., Fosu, S., and Vu, T. (2017). Corporate governance and dividend policy in UK listed SMEs: The effect of board characteristics. International Journal of Accounting and Information Management, Vol. 25 No. 4, pp.459483.

Elsayed, K. (2010). A Multi-theory Perspective of Board Leadership Structure: What Does the Egyptian Corporate Governance Context Tell Us? British Journal of Management, Vol. 21 No.1, pp. 80-99.

Elshandidy, T., \&Hassanein, A. (2014). Do IFRS and board of directors' independence affect accounting conservatism? Applied Financial Economics, Vol. 24 No.16, pp.1091- 1102.

Epstein, M. J., Davila, A., Epstein, M., \& Manzoni, J. F. (2012). Performance Measurement and Management Control: Global Issues (1st ed.). London: Emerald Group PublishingLtd.

Fama, E. F. (1980). Agency Problems and the Theory of the Firm. The journal of political economy, Vol. 88 No.2, pp. 288-307.

Financial Accounting Standards Board (FASB) (2010). Statement of Financial Accounting Concepts No. 8, Conceptual framework for financial reporting. Norwalk, CT: FASB.

Finkelstein, S., \&D'aveni, R. A. (1994). CEO duality as a double-edged sword: How boards of directors balance entrenchment avoidance and unity of command. Academy of Management journal, Vol. 37 No.5, pp. 1079-1108.

Francis, J. R., \& Wang, D. (2008). The joint effect of investor protection and big 4 audits on earnings quality around the world*. Contemporary accounting research, Vol. 25 No.1, pp. 157-191.

García Lara, J. M., Osma, B. G., \&Penalva, F. (2007). Board of directors' characteristics and conditional accounting conservatism: Spanish evidence. European Accounting Review, Vol. 16 No.4, pp. 727-755.

Gigler, F., Kanodia, C., Sapra, H., \&Venugopalan, R. (2009). Accounting conservatism and the efficiency of debt contracts. Journal of Accounting Research, Vol. 47 No.3, pp. 767- 797.

Gillan, S. L. (2006). Recent developments in corporate governance: An overview. Journal of corporate finance, Vol. 12 No.3, pp.381-402.

Givoly, D., \&Hayn, C. (2000). The changing time-series properties of earnings, cash flows and accruals: Has financial reporting become more conservative? Journal of accounting and economics, Vol. 29 No.3, pp.287-320.

Guest, P. M. (2009). The impact of board size on firm performance: evidence from the UK. The European Journal of Finance, Vol. 15 No.4, pp. 385-404.

Gujarati, D. N., \& Porter, D. C. (2009). Basic econometrics (5th ed.). McGraw-Hill, London. 
Haque, F. and Ntim, C.G. (2017). Environmental policy, sustainable development, governance mechanisms and environmental performance. Business Strategy and the Environment, Forthcoming.

Hazarika, S., Karpoff, J. M., \&Nahata, R. (2012). Internal corporate governance, CEO turnover, and earnings management. Journal of Financial Economics, Vol. 104 No.1, pp. $44-69$.

Hermalin, B. E., \&Weisbach, M. S. (2003). Boards of directors as an endogenously determined institution: A survey of the economic literature (No. w8161). Economic Policy ReviewVol.9, pp.7-26.

Jensen, M. C. (1993). The modern industrial revolution, exit, and the failure of internal control systems. The Journal of Finance, Vol. 48 No.8, pp. 831-880.

Jensen, M. C., \&Meckling, W. H. (1976). Theory of the firm: Managerial behavior, agency costs and ownership structure. Journal of financial economics, Vol. 3 No.4, pp. 305- 360.

Khurana, I. K., \& Raman, K. K. (2004). Litigation risk and the financial reporting credibility of Big 4 versus non-Big 4 audits: Evidence from Anglo-American countries. The Accounting Review, Vol. 79 No.2, pp. 473-495.

Kiel, G. C., \& Nicholson, G. J. (2003). Board composition and corporate performance: How the Australian experience informs contrasting theories of corporate governance. Corporate Governance: An International Review, Vol. 11 No.3, pp. 189-205.

Kim, J. B., Chung, R., \& Firth, M. (2003). Auditor Conservatism, Asymmetric Monitoring, and Earnings Management*. Contemporary Accounting Research, Vol. 20 No.2, pp. 323-359.

Klein, A. (1998). Firm performance and board committee structure 1. The Journal of Law and Economics, Vol. 41 No.1, pp. 275-304.

Kukah, M. A., Amidu, M., \& Abor, J. Y. (2016). Corporate governance mechanisms and accounting information quality of listed firms in Ghana. African Journal of Accounting, Auditing and Finance, Vol. 5 No.1, pp. 38-58.

Lafond, R., \&Roychowdhury, S. (2008). Managerial ownership and accounting conservatism. Journal of accounting research, Vol. 46 No.1, pp. 101-135.

Lara, J. M. G., Osma, B. G., \&Penalva, F. (2009). Accounting conservatism and corporate governance. Review of Accounting Studies, Vol. 14 No.1, pp. 161-201.

Letza, S., Kirkbride, J., \& Sun, X. (2004). Shareholding versus stakeholding: A critical review of corporate governance. Corporate Governance: An International Review, Vol. 12 No.3, pp. 242262.

Lim, R. (2011). Are corporate governance attributes associated with accounting conservatism? Accounting \& Finance, Vol. 51 No.4, pp. 1007-1030.

Lipton, M., \&Lorsch, J. W. (1992). A modest proposal for improved corporate governance. The Business Lawyer, pp. 59-77.

Lobo, G. J., \& Zhou, J. (2006). Did conservatism in financial reporting increase after the SarbanesOxley Act? Initial evidence. Accounting Horizons, Vol. 20 No.1, pp.57-73.

Mitra, S., Jaggi, B., \& Al-Hayale, T. (2016). Auditor's Downward Switch, Governance, and Accounting Conservatism. Journal of Accounting, Auditing \& Finance, Vol. 31 No.4, pp. 551-581.

Nicholson, G. J., \& Kiel, G. C. (2007). Can Directors Impact Performance? A case- based test of three theories of corporate governance. Corporate Governance: An International Review, Vol. 15 No.4, 585-608.

Ntim, C.G. (2016). Corporate governance, corporate health accounting and firm value: The case of HIV/AIDS disclosures in Sub-Saharan Africa. International Journal of Accounting, Vol. 51 No. 2, pp.155-216.

Ntim, C.G., Soobaroyen, T., and Broad, M.J. (2017a). Governance structures, voluntary disclosures and public accountability: The case of UK higher education institutions. Accounting, Auditing and Accountability Journal, Vol. 30 No. 1, pp.65-118.

Ntim, C.G., Lindop, S., Thomas, D.A., Abdou, H., and Opong, K.K (2017b). Executive pay and performance: The moderating effect of CEO power and governance structure. International Journal of Human Resource Management, Forthcoming.

Ntim, C.G. (2013a). Monitoring board committee structure and market valuation in large publicly listed South African corporations. International Journal of Managerial and Financial Accounting, Vol. 5 No. 3, pp.310-325. 
Ntim, C.G. (2013b). Corporate ownership and market valuation in South Africa: Uncovering the effects of shareholdings by different groups of corporate insiders and outsiders. International Journal of Business Governance and Ethics, Vol. 8 No. 3, pp.242-264.

Ntim, C.G. (2013c). Corporate Governance, affirmative action and firm value in post-Apartheid South Africa: A simultaneous equation approach. African Development Review, Vol. 25 No. 2, pp.148172.

Ntim, C.G. (2012). Does the South African stock market values independent board dual leadership structure? Economics and Business Letters, Vol. 1 No. 1, pp.35-45

Ntim, C. G. (2009). Internal corporate governance structures and firm financial performance: Evidence from South African listed firms (Doctoral dissertation, University of Glasgow).

Ruch, G. W., \& Taylor, G. (2015). Accounting conservatism: A review of the literature. Journal of Accounting Literature, Vol. 34, pp. 17-38.

Samaha, K., \&Hegazy, M. (2010). An empirical investigation of the use of ISA 520 "analytical procedures" among Big 4 versus non-Big 4 audit firms in Egypt. Managerial Auditing Journal, Vol. 25 No.9, pp. 882-911.

Samaha, K., Dahawy, K., Hussainey, K., \& Stapleton, P. (2012). The extent of corporate governance disclosure and its determinants in a developing market: The case of Egypt. Advances in Accounting, Vol. 28 No.1, pp. 168-178.

Shleifer, A., \&Vishny, R. W. (1997). A survey of corporate governance. The journal of finance, Vol. 52 No.2, pp. 737-783.

Tracey, E. (2015). Discussion of 'Conservatism, prudence and the IASB's conceptual framework' by Richard Barker (2015). Accounting and Business Research, Vol. 45 No.4, pp. 539-542.

Tunyi, A.A. and Ntim, C.G. (2016). Location advantages, governance quality, stock market development and firm characteristics as antecedents of African M\&As. Journal of International Management, Vol. 22 No. 2, pp.147-167.

Wahba, H. (2015). The joint effect of board characteristics on financial performance: Empirical evidence from Egypt. Review of Accounting and Finance, Vol. 14 No.1, pp. 20-40.

Watts, R. L. (2003). Conservatism in accounting part a: Explanations and implications. Accounting horizons, Vol. 17 No.3, pp. 207-221.

Watts, R. L., \& Zimmerman, J. L. (1986). Positive accounting theory. Englewood Cliffs, N.J; Prentice-Hall, London.

Weir, C., \& Laing, D. (2000). The performance-governance relationship: The effects of Cadbury compliance on UK quoted companies. Journal of Management and Governance, Vol. 4 No.4, pp. 265-281.

Weir, C., Laing, D., \& McKnight, P. J. (2002). Internal and external governance mechanisms: their impact on the performance of large UK public companies. Journal of Business Finance \& Accounting, Vol. 29 Nos5/6, pp. 579-611.

Wooldridge, J. M. (2013). Introductory econometrics: A modern approach (5th ed.). South-Western Cengage Learning, Australia.

Xie, B., Davidson, W. N., \&DaDalt, P. J. (2003). Earnings management and corporate governance: the role of the board and the audit committee. Journal of corporate finance, Vol. 9 No.3, pp. 295316.

Yaşar, A. (2013). Big Four Auditors' Audit Quality and Earnings Management: Evidence from Turkish Stock Market. International Journal of Business and Social Science, Vol. 4 No.17, pp. 153-163. 
Table 1: studies on the effect of CG mechanisms on accounting conservatism

\begin{tabular}{|c|c|c|c|c|}
\hline Authors & $\begin{array}{l}\text { Dependent } \\
\text { variable }\end{array}$ & $\begin{array}{l}\text { Corporate governance Independent } \\
\text { variable(s) measured }\end{array}$ & Sample used & Main findings \\
\hline Ahmed \&Duellman (2007) & $\begin{array}{l}\text { Accounting } \\
\text { conservatism }\end{array}$ & $\begin{array}{l}\text { - } \text { Board size } \\
\text { - Insiders on the board } \\
\text { - Separation of chairman /CEO } \\
\text { - Outside director ownership }\end{array}$ & $\begin{array}{l}200 \text { US listed } \\
\text { firms } \\
(1999-2000)\end{array}$ & $\begin{array}{l}\text { - } \quad \text { No significant relation with conservatism. } \\
\text { - } \quad \text {-ve relation with conservatism. } \\
\text { - No significant relation with conservatism. } \\
\text { - } \quad \text { + ve relation with conservatism. }\end{array}$ \\
\hline Garcia Lara et al. (2007) & $\begin{array}{l}\text { Accounting } \\
\text { conservatism }\end{array}$ & $\begin{array}{l}\text { - Strong Governance characteristics } \\
\text { (Aggregate index) }\end{array}$ & $\begin{array}{r}69 \text { Spanish } \\
\text { listed firms } \\
(1997-2002)\end{array}$ & - + ve relation with conservatism. \\
\hline Chi et al. (2009) & $\begin{array}{l}\text { Accounting } \\
\text { conservatism }\end{array}$ & $\begin{array}{ll}\text { - } & \text { Board size } \\
\text { - } & \text { Board expertise } \\
\text { - } & \text { CEO duality } \\
\text { - } & \text { Institutional ownership }\end{array}$ & $\begin{array}{l}\text { 4,181 } \\
\text { Taiwanese } \\
\text { firms- year } \\
\text { observation } \\
(1996-2004)\end{array}$ & $\begin{array}{ll}\text { - } & \text {-ve significant relation with conservatism } \\
\text { - } & \text {-ve significant relation with conservatism } \\
\text { - } & \text { +ve significant relation with conservatism } \\
\text { - } & \text { +ve significant relation with conservatism }\end{array}$ \\
\hline $\operatorname{Lim}(2011)$ & $\begin{array}{l}\text { Accounting } \\
\text { conservatism }\end{array}$ & $\begin{array}{ll}\text { - } & \text { Board size } \\
\text { - } & \text { Independent directors } \\
\text { - } & \text { CEO duality } \\
\text { - } & \text { Big four auditors } \\
\text { - } & \text { Independent directors on AC } \\
\end{array}$ & $\begin{array}{l}644 \text { Australian } \\
\text { firms in (1998) } \\
\text { and } 774 \text { in } \\
\text { (2002) }\end{array}$ & $\begin{array}{l}\text { - } \quad \text { No statistical association with cons. } \\
\text { - No statistical association with cons. } \\
\text { - } \quad \text { Weak -ve association with conservatism } \\
\text { - } \quad \text { + ve relation but not significant. } \\
\text { - } \quad \text { Weak + ve relation with accounting cons. }\end{array}$ \\
\hline Ahmed \& Henry (2012) & $\begin{array}{l}\text { Accounting } \\
\text { conservatism }\end{array}$ & $\begin{array}{ll}\text { - } & \text { Board size } \\
\text { - } & \text { Independent directors } \\
\text { - } & \text { Audit committee }\end{array}$ & $\begin{array}{l}120 \text { Australian } \\
\text { listed firms } \\
(1992-2002)\end{array}$ & $\begin{array}{l}\text { - + ve relation with conservatism. } \\
\text { - + ve relation with conservatism } \\
\text { - + ve relation with conservatism. }\end{array}$ \\
\hline $\begin{array}{l}\text { Elshandiday\& Hassanein } \\
\text { (2014) }\end{array}$ & $\begin{array}{l}\text { Accounting } \\
\text { conservatism }\end{array}$ & $\begin{array}{ll}\text { - } & \text { Board size } \\
\text { - } & \text { Board independence } \\
\text { - } & \text { Separation of chairman /CEO } \\
\end{array}$ & $\begin{array}{l}72 \text { UK listed } \\
\text { fïms } \\
(2002-2007)\end{array}$ & $\begin{array}{l}\text { - No significant relation with conservatism. } \\
\text { - } \quad \text { + ve significant relation with conservatism. } \\
\text { - } \quad \text { + ve significant relation with conservatism. }\end{array}$ \\
\hline
\end{tabular}


Table 2: Summary of sample selection and composition Panel A: Final sample

Eypt

EGX-100 index

\begin{tabular}{lc}
\hline Number of firms & 100 \\
Excluding & $(18)$ \\
Financial and Utilities firms & $(15)$ \\
Missing financial and governance data & 67 firms
\end{tabular}

Panel B: Industrial composition

\begin{tabular}{|c|c|c|}
\hline Industries & $\begin{array}{l}\text { No. of col } \\
\text { each ind }\end{array}$ & $\begin{array}{l}\text { panies in } \\
\text { stry / \% }\end{array}$ \\
\hline Oil \& Gas & 1 & $1.5 \%$ \\
\hline Basic materials & 5 & $7.5 \%$ \\
\hline Industrials & 29 & $43 \%$ \\
\hline Consumer goods & 22 & $33 \%$ \\
\hline Health care & 2 & $3 \%$ \\
\hline Consumer services & 6 & $9 \%$ \\
\hline Telecommunications & 1 & $1.5 \%$ \\
\hline Technology & 1 & $1.5 \%$ \\
\hline Total & 67 firms & $100 \%$ \\
\hline
\end{tabular}


Table 3: Measurements of dependent and independent variables

\begin{tabular}{|c|c|c|}
\hline Variahle & Abbreviations & Variable measurement \\
\hline \multicolumn{3}{|l|}{ Dependent variable: } \\
\hline Accounting conservatism & CONS $_{i t}$ & $\begin{array}{l}\text { Measured based on accrual-based measure of } \\
\text { conservatism following Givoly and Hayn (2000). } \\
\begin{aligned} \text { CONS } & \text { it }=\text { (net income before extraordinary item plus } \\
& \text { depreciation expense less cash flows from operations } \\
& \text { averaged, over } 3 \text { year by total assets and centred } \\
& \text { around year } t) \mathrm{X}-1 .\end{aligned}\end{array}$ \\
\hline \multicolumn{3}{|l|}{ Independent variables: } \\
\hline Board Size & BSIZE & Measured as total number of directors on the board. \\
\hline Board Independence & $\%$ NXD & $\begin{array}{l}\text { Measured as [Number of non- executive directors on } \\
\text { the board / total number of directors on the board] x } \\
100 \% \text {. }\end{array}$ \\
\hline Separation / CEO Duality & S/CEOD & $\begin{array}{l}\text { Measured as dummy variable that takes value of } 1 \text { if } \\
\text { the positions of the company chairman and CEO are } \\
\text { held by different persons and } 0 \text { otherwise. }\end{array}$ \\
\hline Auditor type & AUDT & $\begin{array}{l}\text { Measured as dummy variable that takes the value of } 1 \text {, } \\
\text { if the firm is audited by a big four audit firms and } 0 \\
\text { otherwise. }\end{array}$ \\
\hline \multicolumn{3}{|l|}{ Control variables: } \\
\hline Firm size & FSIZE & Measured as natural log of total assets. \\
\hline Profitability & PROF & Funds from operation/ Sales or revenue \\
\hline Leverage & LEV & Total debts / Total assets \\
\hline Sales Growth & SALESGR & $\begin{array}{l}\text { Current sales less sales of previous year divided by } \\
\text { sales of previous year. }\end{array}$ \\
\hline
\end{tabular}


Table 4: Descriptive statistics for all variables

\begin{tabular}{|c|c|c|c|c|c|}
\hline \multicolumn{2}{|l|}{ Variables } & Mean & SD & Minimum & Maximum \\
\hline \multicolumn{6}{|c|}{ Panel A: Dependent variables } \\
\hline \multicolumn{2}{|c|}{ CONS } & -0.018 & 0.086 & -0.293 & 0.842 \\
\hline \multicolumn{6}{|c|}{ Panel B: Continuous independent variables } \\
\hline \multicolumn{2}{|c|}{ BSIZE } & 7.622 & 2.712 & 3 & 17 \\
\hline \multicolumn{2}{|l|}{ NXD } & 0.705 & 0.204 & 0.000 & 1 \\
\hline \multicolumn{2}{|l|}{ FSIZE } & 13.348 & 1.846 & 10.408 & 1.783 \\
\hline \multicolumn{2}{|l|}{ PROF } & 0.741 & 8.191 & -3.684 & 115.85 \\
\hline \multicolumn{2}{|l|}{ LEV } & 0.389 & 0.248 & 0.002 & 1.152 \\
\hline \multicolumn{2}{|l|}{ SALESGR } & 2.062 & 33.330 & -6.053 & 472.5 \\
\hline \multicolumn{4}{|c|}{ Panel C: Dummy variables } & & Egypt \\
\hline Variables & Dummy & & & $\mathrm{N}$ & $\%$ \\
\hline \multirow[t]{2}{*}{ S/CEOD } & Coded 0 & & & 157 & $78 \%$ \\
\hline & Coded 1 & & & 44 & $22 \%$ \\
\hline \multirow[t]{2}{*}{ AUDT } & Coded 0 & & & 137 & $68 \%$ \\
\hline & Coded 1 & & & 64 & $32 \%$ \\
\hline
\end{tabular}

Notes: CONS is refers to accounting conservatism based on Givoly \&Hayn`s model that measured using equation (1). BSIZE refers to board size. $N X D$ refers to percentage of non-executive directors on the board. FSIZE refers to firm size. PROF refers to the profitability ratio. $L E V$ refers to leverage ratio. $S A L E S G R$ refers to sales growth ratio. S/CEOD refers to separation of chairman and CEO roles. $A U D T$ refers to auditor type. A full definitions for these variables are provided in Table3. 
Table 5: Pearson parametric correlation matrix for all variables in Egyptian contexts.

\begin{tabular}{|l|c|c|c|c|c|c|c|c|}
\hline & CONS & BSIZE & NXD & S/CEOD & AUDT & FSIZE & PROF & LEV \\
\hline CONS & & & & & & & & \\
BSIZE & 0.019 & & & & & & \\
NXD & 0.064 & $0.329^{* *}$ & & & & & & \\
S/CEOD & $\mathbf{0 . 1 5 4}^{*}$ & $-0.153^{*}$ & -0.017 & & & & \\
AUDT & 0.120 & $0.178^{*}$ & 0.0626 & 0.103 & & & \\
FSIZE & $\mathbf{0 . 2 7 8 *}^{* *}$ & $0.346^{* *}$ & -0.121 & $0.144^{*}$ & $0.390^{* *}$ & & & \\
PROF & 0.037 & 0.038 & 0.011 & $0.142^{*}$ & 0.105 & -0.006 & & \\
LEV & $\mathbf{0 . 2 8 1 * *}^{* *}$ & -0.130 & $-0.249^{* *}$ & $0.186^{*}$ & $0.232^{* *}$ & $0.426^{* *}$ & -0.042 & \\
SALESGR & 0.030 & 0.0333 & -0.023 & 0.137 & 0.103 & -0.016 & -0.003 & -0.027 \\
\hline
\end{tabular}

Notes: this table presents Pearson correlation coefficient for Egyptian variables. $* *$ and $*$ indicate statistical significance at the $1 \%$ and $5 \%$ levels, respectively. A full definitions of variables are provided in Table 3 . 
Table 6: Shows the results for regression analysis of accounting conservatism on corporate governance attributes and control variables for both UK and Egypt firms

\begin{tabular}{|c|c|c|c|}
\hline Models & $\begin{array}{c}\text { Egypt } \\
\text { (1) }\end{array}$ & $\begin{array}{c}\text { Egypt } \\
\text { (2) }\end{array}$ & $\begin{array}{c}\text { Egypt-FE } \\
\text { (3) }\end{array}$ \\
\hline Dependent variable & CONS & CONS & CONS \\
\hline \multicolumn{4}{|l|}{ Independent variables } \\
\hline \multirow[t]{2}{*}{ Constant } & -0.024 & -0.237 & -0.842 \\
\hline & $(0.321)$ & $(0.000)^{* * *}$ & $(0.005)^{* *}$ \\
\hline \multirow[t]{2}{*}{$B S I Z E$} & -0.001 & -0.004 & -0.000 \\
\hline & $(0.604)$ & $(0.059)^{*}$ & $(0.939)$ \\
\hline \multirow[t]{2}{*}{$N X D$} & 0.000 & 0.000 & 0.000 \\
\hline & $(0.647)$ & $(0.021)^{* *}$ & $(0.807)$ \\
\hline \multirow[t]{2}{*}{$C E O D$} & 0.0176 & -0.004 & 0.037 \\
\hline & $(0.232)$ & $(0.747)$ & $(0.191)$ \\
\hline \multirow[t]{2}{*}{$A U D T$} & 0.0038 & -0.026 & -0.045 \\
\hline & $(0.768)$ & $(0.047)^{* *}$ & $(0.236)$ \\
\hline \multicolumn{4}{|l|}{ Control variables } \\
\hline \multirow[t]{2}{*}{ FSIZE } & - & 0.013 & 0.057 \\
\hline & & $(0.000)^{* * * *}$ & $(0.010)^{* * *}$ \\
\hline \multirow[t]{2}{*}{ PROF } & - & 0.001 & -0.000 \\
\hline & & $(0.116)$ & $(0.221)$ \\
\hline \multirow[t]{2}{*}{$L E V$} & - & 0.076 & 0.132 \\
\hline & & $(0.004)^{* *}$ & $(0.046)^{* *}$ \\
\hline \multirow[t]{2}{*}{ SALESGR } & - & 0.000 & -0.000 \\
\hline & & $(0.139)$ & $(0.228)$ \\
\hline Adjusted $R^{2}$ & -0.0091 & 0.126 & 0.625 \\
\hline$F$-statistics & & $4.608^{* * *}$ & $5.389^{* * *}$ \\
\hline$N$ & 201 & 201 & 201 \\
\hline Sample period & $2011-2013$ & $2011-2013$ & 2011-2013 \\
\hline Year and firm fixed effects & No & No & Yes \\
\hline
\end{tabular}


